\title{
College Students Attitudes towards Ethical Consumerism - an Indian Perspective
}

\author{
Dr. Kawal Gill \\ (Associate Professor Department of Commerce, Sri Guru Gobind Singh College of Commerce, University of \\ Delhi, India)
}

\begin{abstract}
Business ethics and corporate social responsibility have gained more attention in recent years. However, the consumers 'perspective on ethics is still a little researched area. Ethical consumerism is the intentional purchase of products and services that the customer considers to be made ethically. This may mean with minimal harm to or exploitation of humans, animals and/or the natural environment. Ethical consumerism is practiced through 'positive buying' in that ethical products are favored, or by negative purchasing i.e. through boycotting those product which endanger the health of consumer or others; cause significant damage to environment during manufacture, use or disposal; consume a disproportionate amount of energy; cause unnecessary waste; use materials derived from threatened species or environment or involve unnecessary use or cruelty to animals.

The present study is an attempt to explore and track attitudes of Indian College students towards ethical consumerism in Indian Perspective. College students represent a large and growing population with considerable disposable income. Businesses are also interested in college students because, as trend setters and early adopters they are believed to influence the purchasing decisions of peers and parents and establish brand loyalties that continue long after college.

An empirical survey was conducted for International Marketing students in University of Delhi, India. In all, 210 students took part in the survey. The findings reveal that seventy five percent students described themselves to be ethical consumer to a 'fair amount'. They considered those companies which are known to be socially responsible. Their main purchase consideration was environment friendly (energy efficient) products and they were willing to pay an extra premium up to five percent on the final price. However, there are not many ethical products available and lack of information is the main hurdles/barriers to pursue ethical choices. In cases, where ethical products are widely available consumers have been able to change their attitudes towards ethical consumption.
\end{abstract}

Key Words: consumerism, attitudes, ethical, social responsibility, environment friendly

Defining the ethical consumer

\section{Introduction}

Webster's Online Dictionary describes an "ethical" person as an individual who is likely to "conform to accepted standards of social or professional behaviour". The concept of ethical consumerism is generally accepted as being borne out of the environmental movement and green consumerism. Honduran (2002,) defines green consumerism as that which involves "beliefs and values aimed at supporting greater good that motivates consumers purchases'. Ellington and Hails (1989) elaborate that a green consumer avoids products that might' endanger the health of the consumer or others; cause significant damage to the environment during manufacture, use or disposal; consume a disproportionate amount of energy; cause unnecessary waste; use materials derived from threatened species or environments; involve unnecessary use or cruelty to animals [or] adversely affect other countries".

The distinction between green consumerism and ethical consumerism is important because ethical concern encompasses a broader range of issues and therefore a more complex decision making process for consumers (Shaw and Shia, 2002). Cowed and Williams(2000) therefore extended the green definition to encompass wider ethical issues associated with purchase behaviour, including "matters of conscience such as animal welfare and fair trade, social aspects such as labour standards, as well as more self-interested health concerns behind the growth of organic food sales",

According to Harper and Macaroni (2002), being an ethical consumer means " buying products which are not harmful to the environment and society. This can be as simple as buying free-range eggs or as complex as boycotting goods produced by child labour". 


\section{Three types of ethical consumerism}

Ethical consumerism may be seen as an evolution from earlier consumerism movements. Lang and Hines (1993) identify three waves of consumerism. The first wave of the consumer movement focuses on value for money, basic product information and labelling (what the product does and how) and consumer choice. The second wave was heralded by investigations into product safety and has been associated with broader questions of corporate accountability.

The third wave is described as "marriage of environmentalism and citizenship." Lang and Hines (1993) suggest that it has two distinct forms: - environmental and ethical, Smith (1990), however, suggests that environmental and ethical consumption is essentially the same and that environmental consumerism is just one form of ethical consumerism where the link between "what is consumed and the social problem is more direct."

Third wave of consumerism - ethical consumerism - has three main components: (a) animal welfare; (b) the environment; and (c) human rights/working conditions and fair-trade. Each of the three headings has positive and negative aspects: those products and practices which are upheld and promoted and those which are deplored and avoided/boycotted (Lang and Hines (1993).

\section{Literature Review}

While ethical consumerism has existed for centuries it is only within the last two decades that it has moved from a niche concern to a mainstream phenomenon (Duane, 2001; Lowand Davenport, 2007) attracting growing academic interest (Newham and Shaw, 2007).

The concept of 'ethical consumerism' has demanded much attention from corporations across the business spectrum. Browne et al (2000) describe ethical consumerism as "purchasing decisions that are made with consideration for moral dimensions of how products are produced". The Co-operative Bank (2003) defines it more broadly as "the choice of a product or service ... which supports a particular ethical issue - be it human rights, the environment or animal welfare." Newham and Shaw (2007) in their review of ethical consumerism identified a number of strands of research on ethical and green consumption: the rise of ethical consumerism and academic interest in it; marketing to ethical consumers; consumption morality and sustainability; the creation of opportunities for ethical consumerism; academic discussion on the differing natures of ethical and unethical consumption; and ethical consumption apolitical action or conscious individual projects often described as "shopping for a better world" ( Low and Davenport, 2007).

For a number of years, scholars have argued that a highly principled group of aware and ethical consumers has emerged (e.g., Strong, 1996; Shaw and Clarke, 1998; Shaw and Clarke, 1999, Honduran, 2002; Harrison et al., 2005). They are boycotting real animal fur products, or products that involve the use of animals in product testing. They are also examining a company's record on hiring and promoting minorities and women (Roberts, 1996,). Cowe and Williams (2000,) assert that, "shoppers are highly aware of ethical issues and many are ready to put their money where their morals are". Thus, there is an increasing body of evidence to suggest that shoppers take their morals, in addition to their wallets, when they visit the high street (Thogersen, 1999).

This "ethical shopping basket" is based on household consumption in the areas of food, household goods, cosmetics and toiletries, energy, housing, transport, leisure and charity. Ethical goods and services, defined below, are experiencing growing market shares (Simms,2003) and consumers are becoming more aware ethical consumption through market and information campaigns (Harrison et al., 2005).Direct consumer action in the form of boycott activity, pressure groups and other forms of consumer activism is also on the rise (Augeret al., 2003; Harrison et al., 2005). Hence, it may well be that consumer values are experiencing a shift from the inward facing materialistic outlook, often associated with the "yuppie" mindset of the 1980s, towards a more socially and environmentally proactive mindset, epitomised by what some scholars have labelled the “caringsharing"'1990s (Hemingway and Maclagan, 2004).

This phenomenon is not restricted to Europe. Kahle et al. (1998) note that the American consumer is becoming increasingly concerned with establishing warm relationships with others. More are now pursuing a sense of accomplishment, a notion suggestive of Maslow's goals of self-actualization and self-fulfilment (Solomon et al., 1999). Macchiette and Roy (1994) also report on "Americas concern with social responsibility", as reflected in shifting consumer values. From a national US survey, Fullerton et al. (1996) conclude that consumers overall do have moral values and do not tolerate ethical abuses.

However, in traditional societies, such as India, lifestyles were largely regulated by long-standing practices. Today's postmodern trends - increasing consumerism and affluence, individualism, demographic complexity, ideological diversity, global migration, and constant innovation in communications technology have proliferated new social identities. With rising fragmentation of joint families, greater urbanization, and employment related mobility across cities; the contemporary 'New Age' Urban Indian (NAUI) is constantly faced with an erosion of previously established norms and values. The process has been accentuated by what is popularly called as the 'BPO culture'. This 'culture' has put 'unprecedented money power' in hands of youth 
who have been just out of college. With the advent of consumerism, the NAUI's enacted role as a 'consumer' is gaining far greater importance (Kaul S and Abhishek; 2007).

As consumers in an increasingly free market, NAUI's can choose products to reflect the values they wish to portray. The supply side with proliferation of malls and supermarkets coupled with efficient distribution, down to the last mile, has been fuelling the rise in consumerism. With greater than ever disposable income, easy access to multiple data sources, and living in a consumer dominant environment, the NAUI is largely unconstrained by information, budget or supplier considerations for most consumption decisions. Given the ability and desire to purchase freely, the NAUI is also the recipient of a vast amount of information (Kaul S and Abhishek; 2007)

Against this background, the present study aims to explore and track attitudes of Indian College students towards ethical consumerism. College students represent a large and growing population with considerable disposable income. Businesses are also interested in college students because, as trend setters and early adopters they are believed to influence the purchasing decisions of peers and parents and establish brand loyalties that continue long after college.

\section{Main objective of the Study}

1. Whether college students perceive themselves to be ethical consumers?

2. Whether ethical behaviour gets translated into actual ethical purchase?

3. Whether the information provided by the firms influence their purchase decision?

\section{Online Questionnaire:}

\section{Methodology}

Primary data was collected via an on-line questionnaire comprising of total 15 questions with most of the questions having more than five options each. This formed part of a larger survey investigating ethical consumerism. The aim of on-line collection was to reach a variety of respondents comprising of graduates and post graduate students in the course "International Marketing" in Delhi University, India. In all, 210 students took part in the survey which was conducted over a two month period (April-May 2011). The demographic data is presented in Annexure 1, Table. The questionnaire link was posted on University website, Google discussion forums and subsequently quota sampling was applied.

Effort was made to ensure the format, language and style used in the questionnaire was clear, understandable, aesthetically pleasing and relevant to potential respondents to minimize non-response and the risk of respondents becoming bored or antagonized which could affect the reliability of the questionnaire responses.

The online questionnaire consisted of a combination of open and closed questions. Closed questions were quick to answer which helps improve the response rate and allows easy and direct comparison of responses. Responses to closed questions were all scored on a 5 point Likert scale. Open questions enable respondents to respond freely and were deliberately phrased so as to understand respondents' innate reasons for adopting the 'usage of different categories of ethical products'.

\section{Research Instrument:}

The analysis of data collected from online questionnaire was processed in the form of tables containing item frequencies and percentages, component matrix and rotated component matrix using factor analysis and then using Pearson's correlation with one tailed test at 1 percent significance level through correlation matrix in order to validate results so obtained by factor analysis.

\section{Analysis \\ I To determine whether college students perceive themselves to be ethical consumers?}

To analyze the above question, respondents were asked variety of questions. Their opinions were sought on various factors for making a judgment about the company before taking a purchase decision; various categories and products they would consider for purchasing and the guarantee terms associated with these products; willingness to pay an extra premium for ethical goods and how they would like the premium to be displayed.

Our findings show that out of 210 college students, 157(75\%) respondents perceive themselves as ethical consumers to a 'fair amount' (Annexure 1, Table2) By using rotated component matrix the most important factor that has emerged in respect of judgment about the company, is social responsibility which accounts for 90 percent $(0.9)$ variance (Matrix 1) followed by quality of product and financial performance. 


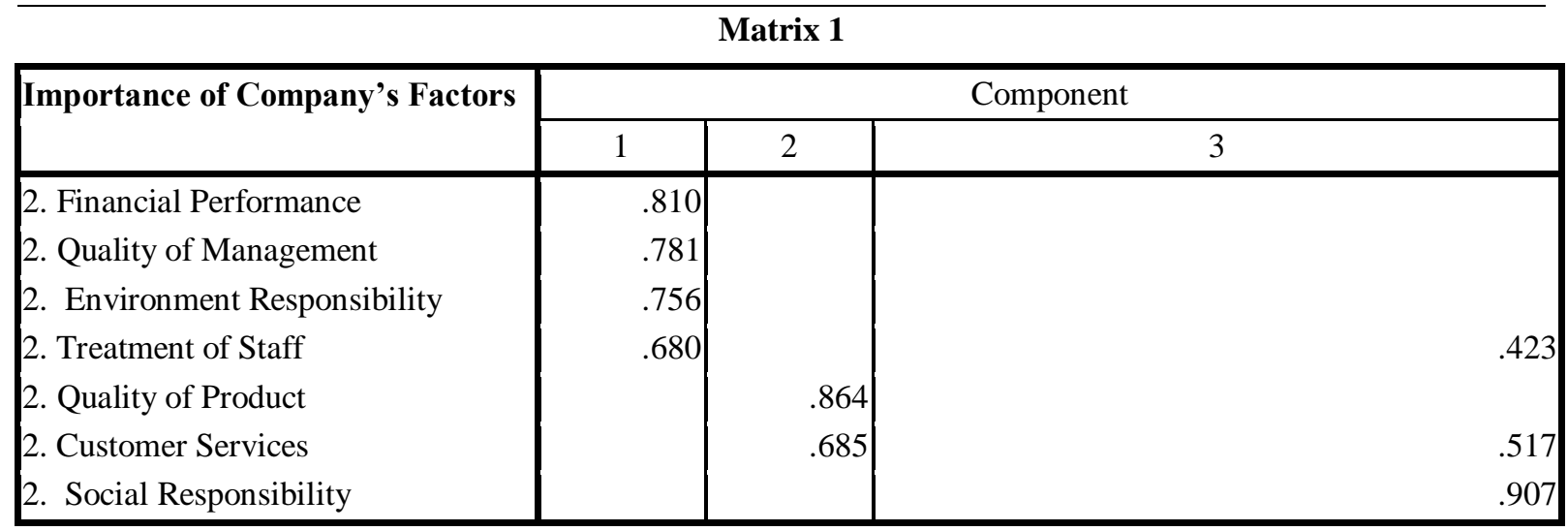

Extraction Method: Principal Component Analysis.

Rotation Method: Varimax with Kaiser Normalization.

While opting for ethical categories, their main purchase consideration was environment friendly (energy efficient) products accounting for almost 77 percent (0.77) variance (Matrix 2). As regarding major category of ethical products, they were mostly interested in buying Compact Fluorescent Lamps (CFL); and Star Rating Air Conditioners and Refrigerators. To buy Fair trade (i.e. providing opportunities to marginalised producers to upgrade their skills, access markets \& seek better prices for their produce) category of ethical goods respondents require guarantee to be given by an external organization rather than from a person either selling or producing a product. This factor accounted for 87 percent (0.87) variance (Matrix 3).

\section{Matrix 2}

\begin{tabular}{|l|r|r|}
\hline \multirow{2}{*}{ Consideration for Ethical Buying } & \multicolumn{2}{|c|}{ Component } \\
\cline { 2 - 3 } & \multicolumn{1}{|c|}{1} & \multicolumn{1}{|c|}{2} \\
\hline 5. People Friendly a) Sweat shop free & .759 & \\
5. Fair trade & .756 & \\
5. Animal friendly a) Not tested on animals & .718 & \\
5. Locally produced & .703 & \\
5. Environmental Friendly e) Reduced packaging & .554 & .437 \\
5. Environmental Friendly a) Energy efficient & & .774 \\
5. Environmental Friendly b) Water efficient & & .753 \\
5. Environmental Friendly c) Forest Sustainable & & .746 \\
5. Organic (i.e. less man made and no pesticides) & & .683 \\
5. Environmental Friendly d) Reduced carbon footprint & & .493 \\
\hline
\end{tabular}

Extraction Method: Principal Component Analysis.

Rotation Method: Varimax with Kaiser Normalization.

Matrix 3

\begin{tabular}{|l|r|r|r|}
\hline & \multicolumn{2}{|c|}{ Component } \\
\cline { 2 - 4 } Ethical Category for Guarantee & \multicolumn{1}{|c|}{ 1 } & \multicolumn{1}{|c|}{3} \\
\hline 6. Animal friendly a) Not tested on animals & .790 & & \\
6. People Friendly a) Sweat shop free & .743 & & \\
6. Environmental Friendly b) Water efficient & .638 & .527 & \\
6. Environmental Friendly e) Reduced packaging & .634 & & \\
6. Environmental Friendly c) Forest Sustainable & .624 & .404 & \\
6.Environmental Friendly a) Energy efficient & & .803 & \\
6. Organic (i.e. less man made and no pesticides) & & .724 & \\
6. Environmental Friendly d) Reduced carbon footprint & & .594 & \\
6. Fair trade & & & .871 \\
6. Locally produced & & & .532 \\
\hline
\end{tabular}


Extraction Method: Principal Component Analysis.

Rotation Method: Varimax with Kaiser Normalization.

Majority of respondents 'were always willing' to pay the amount of premium up-to 5 percent accounting for 85.7 percent $(0.857)$ variance. They also wanted the premium to be displayed explicitly on final price. This factor accounted for 75.7 percent (0.757) variance (Matrix 4 and 5).

\section{Matrix 4}

\begin{tabular}{|c|c|}
\hline \multirow[b]{2}{*}{ Amount of Premium Willing to Pay } & Component \\
\hline & 1 \\
\hline 7. premium up to $5 \%$ & .857 \\
\hline 7. Payment of extra price & .851 \\
\hline 7. Premium over $5 \%$ & .790 \\
\hline
\end{tabular}

Extraction Method: Principal Component Analysis.

Matrix 5

\begin{tabular}{|l|r|}
\hline & \multicolumn{2}{|c|}{ Component } \\
\cline { 2 - 2 } Display of Premium to be Paid & 1 \\
\hline 8. Premium explicitly stated on final price & .757 \\
8. premium implicit in final price & \\
\hline
\end{tabular}

Extraction Method: Principal Component Analysis.

These results were further validated with applying Spearman's correlation technique. Correlation Matrix I shows that purchase of ethical category (such as CFLs, Star Rating ACs) was highly correlated with desire for social responsiveness (.231) at the significance level of 5 percent and with as energy efficient environmental friendly products (.361) as well as with explicitly stated premium on final price (.320) at the significance level of 1 percent(Annexure 2). Payment of extra price up to 5 percent is highly correlated with explicitly stated premium paid on final price of ethical products (.295) at the significance level of 1 percent.

Out of the above two options, we found that purchase of ethical category of products (such as CFLs, Star Rating ACs) was highly correlated with energy efficient environmental friendly (.361) at the significance level of 1 percent since its results are more accurate with lesser possibilities of errors as compared to 5 percent significance level.

Analysis of the responses to influential factors reveal that high scores on respondents perception on ethical consumerism were positively correlated with high desirability of social responsibility scores which suggests that majority of the respondents would like to purchase ethical goods as part of their social responsibility and growing concerns for the environment.

\section{To determine whether ethical behaviour gets translated into actual ethical purchase?}

Awareness of environmental and social issues does appear to be rising. However, there is a disparity between increased awareness and ethical purchase behaviour. There may be differences between what people do and what they say they do. Here, we wanted to find out if disparity existed and if yes than what are the main reasons behind it.

We asked a number of questions to the respondents e.g. whether in the last one year they have chosen products on the company responsible reputation; recommended company because of responsible reputation; bought to support local shops / suppliers; Bought recycled materials or given waste material for recycling; avoided products because of the company's reputation e.g. Nike, Addidas, Coca-Cola, Pepsi, L'Oreal, Nestle; bought primarily for ethical reasons e.g. jute Bags ILO plastic bags; actively taken a membership of any environmental group e.g. PETA, WWF; sought information on company's behaviour / policies; actively campaigned about environmental/ social issue e.g. earth hour, pooling of cars \& use of public transport, organic farming etc.

Respondents were also asked to list any ethical goods they had purchased in the last year and their opinions were sought on the barriers to ethical purchase from the number of options given to them likeenvironmentally preferable products may not meet consumer criteria of price, performance, quality and easy access; the information about environmental benefits of products is insufficient; on-pack information lacks credibility with consumers; there are not enough environmentally good products in the market; the depth of 
knowledge about environmental issues is limited; people do not have the time to look for products that are kinder to the environment; people feel they cannot make much difference; many people have little inclination to pay a premium.

Our findings show that while making purchases in last one year, they 'always look to support local shops and suppliers'. This factor emerged as the most important factor as it accounted for 80.4 percent $(0.804)$ variance closely followed by second important factor that 'they recommended company because of its responsible reputation' accounting for 80.2 percent $(0.802)$ variation ( Matrix 6 ).

\section{Matrix 6}

\begin{tabular}{|l|r|r|}
\hline Purpose of Ethical Buying in last 12 Months & \multicolumn{2}{|c|}{ Component } \\
\cline { 2 - 3 } & \multicolumn{1}{|c|}{1} & \multicolumn{1}{|c|}{2} \\
\hline 3. Recommended company because of responsible reputation & .802 & \\
3. Chosen products on the company responsible reputation & .799 & \\
3. Bought to support local shops / suppliers & & .804 \\
3. Purchase of recycled materials or given waste material for & & .718 \\
recycling & .547 & .636 \\
3. Talked to friends/family about companies behaviour & & \\
\hline
\end{tabular}

Extraction Method: Principal Component Analysis.

Rotation Method: Varimax with Kaiser Normalization.

Majority of respondents say that before they bought goods 'they always sought information on companies' behaviour and policies. This factor accounts for 80.5 percent $(0.805)$ variation (Matrix7)

Matrix 7

\begin{tabular}{|l|r|}
\hline Information sought before making ethical purchases in last 12 \\
months
\end{tabular}

Extraction Method: Principal Component Analysis.

Open ended question about listing the ethical products bought in the last 12 months revealed that these college students bought variety of goods like cane furniture; eco friendly furniture and t shirts; solar water heater; notebooks and copies (recycled); jute neck ties; Khadi soap; unleaded petrol; jute bags; organic food and vegetables; CNG cars; CFLs; clothing; star rating ACs and refrigerators, recycled paper, chocolates, coffee, biodegradable shoes, stationary, Fab India creams, soaps, tea, herbs, cosmetics, clay pots, juices, mobile phones made up of recycled components, etc. Out of these, the major ethical category of product chosen was energy efficient environmental friendly products such as CFLs and star rating ACs amounting to (0.852) variation (Matrix 8).

\section{Matrix 8}

\begin{tabular}{|c|c|c|c|c|}
\hline \multirow[t]{2}{*}{ Ethical Products Interested to Purchase } & \multicolumn{4}{|c|}{ Component } \\
\hline & 1 & 2 & 3 & 4 \\
\hline $\begin{array}{l}\text { 9. Kitchen Supplies } \\
\text { 9. Office \& stationery } \\
\text { 9. Flowers } \\
\text { 9. Books }\end{array}$ & $\begin{array}{l}.772 \\
.669 \\
.645 \\
.571\end{array}$ & .500 & .563 & \\
\hline
\end{tabular}




\begin{tabular}{|c|c|c|c|c|}
\hline $\begin{array}{l}\text { 9. Coffee and Tea } \\
\text { 9. Clothing } \\
\text { 9. Food } \\
\text { 9. Chocolate } \\
\text { 9. CFLs \& Star Rating ACs, Refrigerators } \\
\text { 9. Music \& Videos }\end{array}$ & .562 & $\begin{array}{l}.768 \\
.730\end{array}$ & .405 & $\begin{array}{r}.852 \\
-.555\end{array}$ \\
\hline
\end{tabular}

Extraction Method: Principal Component Analysis.

Rotation Method: Varimax with Kaiser Normalization.

As regarding the barriers to ethical buying, respondents strongly agree that 'there are not enough environmental products in the market'. This factor has accounted for 92 percent (0.920) variance followed by second factor i.e. 'many people have little inclination to pay a premium' (0.904) and third factor 'environmentally preferable products may not meet consumer criteria of price, performance, quality and easy access' (.826),(Matrix9).

\begin{tabular}{|c|c|c|c|c|}
\hline \multirow[b]{3}{*}{ Barriers to Ethical Buying } & & & & \\
\hline & \multicolumn{4}{|c|}{ Component } \\
\hline & 1 & 2 & 3 & 4 \\
\hline 15 Time Limitation & .881 & & & \\
\hline 15 No difference & .816 & & & \\
\hline 15. Unmet consumer criteria & & .826 & & \\
\hline 15 Insufficient Information & & .703 & & \\
\hline 15 limited knowledge on environmental issues & .406 & .443 & & \\
\hline 15 Little inclination to pay a premium & & & .904 & \\
\hline 15 Lack of consumer credibility & & .437 & .531 & \\
\hline 15 Not enough environmental products & & & & .920 \\
\hline
\end{tabular}

Extraction Method: Principal Component Analysis.

Rotation Method: Varimax with Kaiser Normalization

Correlation Matrix II (Anneure2) shows that consumers' ethical purchases to support local shops \& manufacturers were highly correlated with gathering information on company's behaviour \& policies (.389) at the significance level of 1 percent.

The link between desire for socially responsible behaviour and environmental influences suggest that the attitudes and opinions of others in the wider context play a role in the decision to use environmental friendly products. But some of these products are bought after careful selection of the manufacturer on the basis of its reputation and corporate social responsibility. However, many ethical goods are not as widely available as others and consumers have not much information on the environmental costs and benefits.

\section{To determine whether the information on ethical behaviour provided by the firms influence their purchase decision?}

To evaluate the third research objective, we wanted to take respondents opinion on the influence of ethics in consumer choice. Table 3(Annexure 1) displays the results of the questions concerning ethics and consumer decision making. Indian consumers seem to consider ethics to be 'very important' in business, 47.6 percent of the respondents shared this opinion while 42 percent regarded this as 'important'.

Consumers need reliable and accurate information about the business-related ethical issues in order to make decisions. Table 4(Annexure 1) gives the results about reliability of information provided by the firms. 49.6 percent of the respondents regarded the information given by firms as 'rather reliable', only 4.2 percent of them viewed it as highly 'reliable'. Moreover, more than one-fourth of them viewed this information as 'rather unreliable' (27.7 percent). This suggests that one important condition of ethical consumerism - availability of accurate information - is still insufficient.

The perceived importance of ethics does not automatically translate into consumers' decision making. Table 5 (Annexure 1) shows that majority of the respondents stated that a firm's business ethics influence their purchasing behaviour; 21.3 percent said that ethics have a 'strong influence' and 60.4 percent said that ethics 
have 'some influence' on their choices. The remainder of the respondents (12 percent) reported that ethics have either a 'small influence' or 'no influence' at all ( 2.9 percent).

We wanted to know how consumers viewed the various information sources, in particular, how various sources perform in conveying information about firms' ethical conduct. Rotated component matrix 10 displays the results. The respondents regarded consumer authorities as the most important factor accounting for 87.8 percent (.878) variance. Choice for 'importers' was the second factor followed by 'friend's recommendation'; 'trademarks and labels' and 'internet' (Matrix 10).

\section{Matrix 10}

\begin{tabular}{|l|r|r|r|}
\hline Source of Information about ethical products & \multicolumn{3}{|c|}{ Component } \\
\cline { 2 - 4 } & \multicolumn{1}{|c|}{1} & \multicolumn{1}{|c|}{. } \\
\hline 11. Trademark/label & .750 & & \\
11. Stores/in-store staff & .713 & & \\
11. Internet & .706 & .412 & \\
11. Magazines/literature & .597 & & \\
11.[Other people/friends & & .798 & \\
11. Brochures & & .617 & \\
11. Television & & .556 & \\
11. Consumer authorities & & & .878 \\
11. Importers & & & .760 \\
\hline
\end{tabular}

Extraction Method: Principal Component Analysis.

Rotation Method: Varimax with Kaiser Normalization

Correlation Matrix III (Annexure 2) shows that ethical influence on purchases was highly correlated with importers (.374) as well as with firm's ethical practices (.389) at the significance level of 1 percent \& consumer authorities (.228) at the significance level of 5 percent. Firms' ethical practice was highly correlated with reliability of information (.220) at the significance level of 5 percent. Importers and consumer authorities are highly correlated (.428) at the significance level of 1 percent.

Hence, from above we found that ethical influence on purchases was highly correlated with importers (.374) as well as with firm's ethical practices (.389) and also importers and consumer authorities were also highly correlated (.428) at the significance level of 1 percent giving more accuracy to our results.

The correlation between reliable information provided by importers, consumer authorities and its influence on ethical purchase decisions indicate that respondents think that availability and disclosure of such information can result in positive buying behaviour.

\section{Discussion, Conclusions and Practical Implications}

In this study, we were interested in identifying whether college students perceived themselves to be ethical buyers assuming they have fair amount of educational background and awareness about social responsibility, concerns about environment, animal welfare, willing to pay an extra price for healthy options and so on.

In answer to first research objective, our findings, supported by the factor analysis and summary of tables as well as correlation matrices suggests that respondents perceive themselves as ethical consumers to a fair amount. Majority of respondents suggested social responsibility was the important factor in buying environmental friendly products (energy, water efficient and forest sustainable products).

However, in order to make ethical choices, consumers need information. Currently, because of the proliferation of brands and images, consumers may find it difficult to form a reasonable judgment about the products to be bought. Moreover, many consumers are uncertain about which firms conduct ethical practices and which do not; which products are ethically produced and which are not and why.

On the contrary, consumers have shown a positive buying behaviour where they are sure about manufacturer's ethical reputation, potential benefits attached to the usage of these goods and above all where their environmental concerns are met. As per the items listed in the open ended question, most of the items are widely available in the Indian market at a very competitive price and consumers have enough information on their environmental benefits. Out of the list, almost fifty percent of the items are made by small and medium sized companies whereas in case of energy efficient products life CFLS and star rating ACs and refrigerators, leading multinationals dominate the Indian market e.g. Phillips in CFL; Samsung, LG, Hitachi, Whirlpool in star rating appliances. 
The Indian market is experiencing a high growth rate in energy efficient products and this has happened mainly because of increased awareness by energy conservation campaigns run by government departments, NGOs and business houses. Economic growth coupled with higher disposable income, growth in the construction sector and are the other key factors leading to a high growth rate in this market. This phenomenon has attracted a number of worldwide lighting majors as well as domestic businesses. The size of the CFL market currently at 230 million units is expected to exceed 400 million units by the year 2014 . The market is being driven both by growing adoption by new consumers as well as replacements. The CFL Market of India stands at USD 250 million currently and is growing rapidly.

So, the above examples reinforce our findings that awareness and availability of environmental products can change the attitudes of consumers towards ethical consumption whereas lack of awareness and non availability of the same can act as a potential barrier in the usage of ethical goods. This lack of information means that companies must explain not only their own products but also the larger issues of pollution, climate change, overfishing and other environmental problems. Of crucial importance here will be the development of governmental regulation of corporate disclosure, environmental claims and general information availability. Nonprofits and government agencies should also take up the cause of ethical education.

Further, our findings highlight the role of consumer authorities and importers as a major source of providing reliable ethical information. It also suggests the need for government to continue reinforcing actions in causing the behaviour shift towards ethical buying.

Hence, this review of trends in ethical consumer activity and recent research has highlighted the fact that consumers are more informed and educated than before, and aware of what is required of products as well as their rights and responsibilities as consumers. However, this awareness does not necessarily imply better consumption decisions or more ethical choices.

The purchase and consumption of ethical products require that a large amount of effort be invested in information acquisition and decision making. In addition, consumers have to be willing to pay higher prices for these products. To realize the ethical market's true potential, businesses and Governmental action must help consumers change their behaviour by removing the hurdles/ barriers between intentions and actions.

\section{Limitations and Scope for Future Research}

This study examined the ethical perceptions college students hold towards making purchase decisions. The first limitation of this study was that it was limited to International Marketing students at the University of Delhi. To increase the number and diversity of respondents a larger population of students should be surveyed from various other courses e.g. sciences, humanities and social sciences being run in the university.

The current survey had a total of fifteen questions, most of the questions having more than five options each. In order to obtain a more comprehensive study, a larger group of questions may need to be devised and more open questions can be added. Although the current survey was sufficient for addressing the purpose of this study.

Ethical issues are not only complicated, but also difficult to study. It cannot be determined if respondents are giving socially desirable responses. This causes the problem of determining if respondents are giving true and sincere responses to questions pertaining to their actual ethical beliefs while purchasing goods.

This study's results do leave room for further research to be done to expand and work towards developing strategies to help deter consumers from purchasing goods made unethically. It may be, further education needs to take place among consumers to the negative effects these goods hold within society or that stricter penalties need to be set in place to deter not only the manufactures of these goods but the consumers as well.

[1] Auger, P., P. Burke, T. M. Devinney and J. J. Louviere: 2003, What Will Consumers Pay for Social Product Features? Journal of Business Ethics 42(3), 281-304.

[2] Browne AW, Harris PJ, Hofney-Collins AH, Pasiecznik N, and Wallace RR. 2000. Organic

[3] Production and Ethical Trade: Definition, practice and links. Food Policy 25 (1): 69-89.

[4] Cowe, R. and S. Williams: 2000, Who Are the Ethical Consumers? Co-operative Bank Report, 1-44.

[5] Doane D, 2001, Taking flight: The rapid growth of ethical consumerism, the ethical purchasing index 2001. New Economics Foundation: London.

[6] Elkington, J. and J. Hailes: 1989, The Green Consumer's Shopping Guide (Gollancz, London).

[7] Harper, G. C. and A. Makatouni: 2002, _Consumer Perception of Organic Food Production and Farm Animal Welfare, British Food Journal 104(3), 287-299.

[8] Fullerton, S., K. B. Kerch and H. R. Dodge: 1996, Consumer Ethics: An Assessment of Individual Behaviour in the Marketplace, Journal of Business Ethics 15(7), 805-814.

[9] Harrison, R., T. Newholm and D. Shaw: 2005, The Ethical Consumer (Sage, London).

[10] Hendarwan, E.: 2002, Seeing Green, Global Cosmetic Industry 170(5), 16-18.

[11] Hemingway, C. A. and P. W. Maclagan: 2004, Managers Personal Values as Drivers of Corporate Social Responsibility, Journal of Business Ethics 50(1), 33-44.

[12] Kahle, L. R., B. Poulos and A. Sukhdial: 1998, Changes in Social Values in the United States During the Past Decade_, Journal of Advertising Research 38(4), 35-41. 
[13] Kaul S and Abhishek, (2007) Consumerism and Mindless Consumption Sustaining the New Age Urban Indian's Identity, Conference Proceedings; International Marketing Conference on Marketing and Society; Indian Institute of Management Kozhikode, April 2007.

[14] LANG, T. and HINES, C. (1993), The New Protectionism. London: Earth scan Publications.

[15] Low W, Davenport E. 2007. To boldly go ... exploring ethical spaces to re-politicise ethical consumption and fair trade. Journal of Consumer Behaviour 6 (5): 336-348

[16] Macchiette, B. and A. Roy: 1994, _Sensitive Groups and Social Issues. Are You Marketing Correct?, Journal of Consumer Marketing 11(4), 55-64.

[17] Mckinsey, 2008, Helping green products grow.

[18] M. Freestone and J. McGoldrick, (2008), Motivations of the Ethical Consumer, Journal of Business Ethics, DOI 10.1007/s10551007-9409-1

[19] Newholm T, Shaw D. 2007. Studying the ethical consumer: A review of research. Journal of Consumer Behaviour 6 (5): 253-270.

[20] Roberts, J. A.: 1996, _Will the Real Socially Responsible Consumer Please Step Forward? _, Business Horizons 39(1), 79-83.

[21] Shaw, D. and I. Clarke: 1998,_Culture, Consumption and Choice: Towards a Conceptual Relationship, Journal of Consumer Studies and Home Economics 22(3), 163-168.

[22] Shaw, D. and I. Clarke: 1999, _Belief Formation in Ethical Consumer Groups: An Exploratory Study, Marketing Intelligence and Planning 17(2), 109-119.

[23] Shaw, D. and E. Shiu: 2002,_An Assessment of Ethical Obligation and Self-Identity in Ethical Consumer Decision-Making: A Structural Equation Modelling Approach, International Journal of Consumer Studies 26(4), 286-293.

[24] Simms, J.: 2003, Fair Chance for Fair Trade? Marketing, July 3rd, 22.

[25] Solomon, M. R., G. Bamossy and S. Askegaard: 1999, Consumer Behaviour: A European Perspective (Prentice-Hall, Harlow, UK).

[26] SMITH, N. C. (1990) Morality and the Market. Consumer Pressure for Corporate Accountability. London: Routledge.

[27] Strong, C.: 1996,_Features Contributing to the Growth of Ethical Consumerism - A Preliminary Investigation, Marketing Intelligence and Planning 14(5), 5-13.

[28] Thogersen, J.: 1999,_The Ethical Consumer. Moral Norms and Packaging Choice_, Journal of Consumer Policy 22(4), 439-460.

[29] Sourced 12.4.11 at <http://www.websters-onlinedictionary.org/definition/ethical>.

[30] The Co-operative Bank', website www.co-operativebank. co.uk

[31] Tallontire A, Rentsendorj E and Blowfield M, Ethical Consumers and Ethical Trade: a review of Current literature, policy series 12

\begin{tabular}{|c|c|c|c|c|c|c|}
\hline \multicolumn{7}{|c|}{$\begin{array}{c}\text { Annexure 1 } \\
\text { Table 1 - DEMOGRAPHIC DATA } \\
\end{array}$} \\
\hline \multicolumn{2}{|l|}{$N=210$} & N1 & $\%$ & & N2 & $\%$ \\
\hline GENDER & MALE & 109 & $51.9 \%$ & FEMALE & 101 & $48.09 \%$ \\
\hline \multicolumn{2}{|c|}{$\mathrm{N}=\mathrm{N} 1+\mathrm{N} 2=210$} & \multicolumn{2}{|c|}{$\mathrm{N} 1=109$} & & \multicolumn{2}{|c|}{$\mathrm{N} 2=101$} \\
\hline \multirow[t]{3}{*}{$\underline{\mathrm{AGE}}$} & 20-22 YRS & \multicolumn{2}{|c|}{69} & 20-22 YRS & \multicolumn{2}{|c|}{48} \\
\hline & 23-25 YRS & \multicolumn{2}{|c|}{36} & 23-25 YRS & \multicolumn{2}{|c|}{51} \\
\hline & $26 \&$ ABOVE & \multicolumn{2}{|c|}{04} & $26 \&$ ABOVE & \multicolumn{2}{|c|}{02} \\
\hline \multirow{2}{*}{ EDUCATION } & Graduation & 43 & $39.4 \%$ & \multirow{2}{*}{$\begin{array}{l}\text { Graduation } \\
\text { Post } \\
\text { Graduation }\end{array}$} & 46 & $45.5 \%$ \\
\hline & $\begin{array}{l}\text { Post } \\
\text { Graduation }\end{array}$ & 66 & $60.6 \%$ & & 55 & $54.5 \%$ \\
\hline
\end{tabular}

Q1.

TABLE 2 - CONSUMERS ETHICAL PERCEPTION

\begin{tabular}{|}
$\mid$\begin{tabular}{|c|c|c|c|c|c|}
\hline \multicolumn{5}{|c|}{ CONSUMERS ETHICAL PERCEPTION } \\
\hline N=210 & $\frac{\text { GREAT }}{\text { DEAL }}$ & $\underline{\underline{\text { AMOUNT }}}$ & $\frac{\underline{\text { NOT VERY }}}{\text { MUCH }}$ & $\underline{\text { NOT AT ALL }}$ & DON'T KNOW \\
\hline frequency & 34 & 157 & 13 & 0 & 6 \\
\hline percent & $16 \%$ & $75 \%$ & $6.1 \%$ & Nil & $2.9 \%$ \\
\hline
\end{tabular}
\end{tabular}


TABLE 3 - IMPORTANCE OF FIRM'S ETHICAL PRACTICE Q12.

\begin{tabular}{|c|c|c|c|c|c|}
\hline \multicolumn{6}{|c|}{ IMPORTANCE OF FIRM'S ETHICAL PRACTICE } \\
\hline $\begin{array}{l}N= \\
210\end{array}$ & $\frac{\frac{\text { VERY }}{\text { IMPORT }}}{\underline{\text { ANT }}}$ & $\frac{\frac{\text { RATHER }}{\text { IMPORTA }}}{\underline{\text { NT }}}$ & $\begin{array}{l}\text { RATHER } \\
\text { UNIMPORTANT }\end{array}$ & $\frac{\text { UNIMPORTA }}{\underline{\text { NT }}}$ & $\underline{\text { DON'T KNOW }}$ \\
\hline $\begin{array}{l}\text { numbe } \\
\mathbf{r}\end{array}$ & 100 & 88 & 12 & 6 & 4 \\
\hline $\begin{array}{l}\text { percen } \\
t\end{array}$ & $47.6 \%$ & $42 \%$ & $5.8 \%$ & $2.8 \%$ & $1.8 \%$ \\
\hline
\end{tabular}

Q13.

TABLE 4 - RELIABILITY OF FIRM'S ETHICAL INFORMATION

\begin{tabular}{|c|c|c|c|c|c|}
\hline \multicolumn{6}{|c|}{ RELIABILITY OF FIRM'S ETHICAL INFORMATION } \\
\hline $\mathbf{N}=\mathbf{2 1 0}$ & $\frac{\text { VERY }}{\text { RELIABLE }}$ & $\frac{\text { RATHER }}{\text { RELIABLE }}$ & $\frac{\frac{\text { RATHER }}{\text { UNRELIABL }}}{\underline{E}}$ & UNRELIABLE & DON'T KNOW \\
\hline $\begin{array}{l}\text { frequenc } \\
\mathbf{y}\end{array}$ & 31 & 104 & 58 & 9 & 8 \\
\hline percent & $14.7 \%$ & $49.6 \%$ & $27.7 \%$ & $4.2 \%$ & $3.8 \%$ \\
\hline
\end{tabular}

TABLE 5 - DEGREE OF FIRM'S ETHICAL INFFLUENCE ON PURCHASE DECISION Q14.

\begin{tabular}{|c|c|c|c|c|c|}
\hline \multicolumn{6}{|c|}{ DEGREE OF FIRM'S ETHICAL INFFLUENCE ON PURCHASE DECISION } \\
\hline$N=\mathbf{2 1 0}$ & $\begin{array}{l}\frac{\text { SIGNIFICAN }}{T} \\
\text { INFLÜENCE }\end{array}$ & $\frac{\text { SOME }}{\text { INFLUENCE }}$ & $\begin{array}{l}\frac{\text { LITTLE }}{\text { INFLUEN }} \\
\underline{\text { CE }}\end{array}$ & $\frac{\frac{\text { NO }}{\text { INFLUENC }}}{\underline{E}}$ & $\begin{array}{l}\text { DON'T } \\
\text { KNOW }\end{array}$ \\
\hline frequency & 46 & 127 & 25 & 6 & 6 \\
\hline percent & $21.3 \%$ & $60.4 \%$ & $12 \%$ & 2.9 & 2.9 \\
\hline
\end{tabular}


Correlation (I)

\begin{tabular}{|c|c|c|c|c|c|c|}
\hline $\begin{array}{c}\text { PEARSON } \\
\text { CORRELATION } \\
\text { Sig. }(1-\text { Tailed Test }) \\
\mathbf{N} \\
\end{array}$ & $\begin{array}{l}\text { 2. Social } \\
\text { Responsibility }\end{array}$ & $\begin{array}{l}\text { 3. Bought to } \\
\text { support local } \\
\text { shops/ } \\
\text { suppliers }\end{array}$ & $\begin{array}{l}\text { 5. Environmental } \\
\text { Friendly } \\
\text { a) Energy efficient }\end{array}$ & $\begin{array}{l}\text { 7. Payment } \\
\text { of extra price }\end{array}$ & $\begin{array}{l}\text { 8. Premium } \\
\text { explicitly } \\
\text { stated on } \\
\text { final price }\end{array}$ & $\begin{array}{l}\text { 9. CFLs \& } \\
\text { Star Rating } \\
\text { ACs, } \\
\text { Refrigerators }\end{array}$ \\
\hline $\begin{array}{c}\text { 2. Social } \\
\text { Responsibility }\end{array}$ & $\begin{array}{r}1.000 \\
69.000 \\
\end{array}$ & $\begin{array}{c}-.050 \\
.341 \\
69 \\
\end{array}$ & $\begin{array}{l}.117 \\
.170 \\
69 \\
\end{array}$ & $\begin{array}{l}.170 \\
.082 \\
69 \\
\end{array}$ & $\begin{array}{c}-.047 \\
.350 \\
69 \\
\end{array}$ & $\begin{array}{c}.231^{*} \\
.028 \\
69 \\
\end{array}$ \\
\hline $\begin{array}{l}\text { 3. Bought to support } \\
\text { local shops / } \\
\text { suppliers }\end{array}$ & $\begin{array}{c}-.050 \\
.341 \\
69\end{array}$ & $\begin{array}{r}1.000 \\
69.000\end{array}$ & $\begin{array}{l}.038 \\
.379 \\
69\end{array}$ & $\begin{array}{c}.119 \\
.164 \\
69\end{array}$ & $\begin{array}{c}.124 \\
.154 \\
69\end{array}$ & $\begin{array}{l}.016 \\
.449 \\
69\end{array}$ \\
\hline $\begin{array}{c}\text { 5. Environmental } \\
\text { Friendly a) Energy } \\
\text { efficient }\end{array}$ & $\begin{array}{l}.117 \\
.170 \\
69 \\
\end{array}$ & $\begin{array}{c}.038 \\
.379 \\
69 \\
\end{array}$ & 1.000 & $\begin{array}{r}-.073 \\
.275 \\
69 \\
\end{array}$ & $\begin{array}{c}.143 \\
.120 \\
69 \\
\end{array}$ & $\begin{array}{c}.361^{* *} \\
.001 \\
69\end{array}$ \\
\hline $\begin{array}{c}\text { 7. Payment of extra } \\
\text { price }\end{array}$ & $\begin{array}{l}.170 \\
.082 \\
69 \\
\end{array}$ & $\begin{array}{c}.119 \\
.164 \\
69 \\
\end{array}$ & $\begin{array}{c}-.073 \\
.275 \\
69 \\
\end{array}$ & $\begin{array}{r}1.000 \\
69.000 \\
\end{array}$ & $\begin{array}{c}.295^{* *} \\
.007 \\
69 \\
\end{array}$ & $\begin{array}{l}.165 \\
.088 \\
69 \\
\end{array}$ \\
\hline $\begin{array}{l}\text { 8. Premium } \\
\text { explicitly stated on } \\
\text { final price }\end{array}$ & $\begin{array}{c}-.047 \\
.350 \\
69\end{array}$ & $\begin{array}{c}.124 \\
.154 \\
69\end{array}$ & $\begin{array}{l}.143 \\
.120 \\
69\end{array}$ & $\begin{array}{c}.295^{* *} \\
.007 \\
69\end{array}$ & $\begin{array}{l}1.000 \\
69.000\end{array}$ & $\begin{array}{c}.320^{* *} \\
.004 \\
69\end{array}$ \\
\hline $\begin{array}{l}\text { 9. CFLs \& Star } \\
\text { Rating ACs, } \\
\text { Refrigerators }\end{array}$ & $\begin{array}{l}.231^{*} \\
.028 \\
69\end{array}$ & $\begin{array}{c}.016 \\
.449 \\
69\end{array}$ & $\begin{array}{c}\frac{361^{* *}}{.001} \\
69\end{array}$ & $\begin{array}{l}.165 \\
.088 \\
69\end{array}$ & $\begin{array}{c}.320^{* *} \\
.004 \\
69\end{array}$ & 1.000 \\
\hline
\end{tabular}

*.Correlation is significant at the 0.05 level (1-tailed test)

**. Correlation is significant the 0.01 level (1-tailed test) 
College Students Attitudes towards Ethical Consumerism - an Indian Perspective

\begin{tabular}{|c|c|c|c|}
\hline $\begin{array}{c}\text { PEARSON } \\
\text { CORRELATION } \\
\text { Sig. }(1-\underset{\text { Tailed Test }}{\text { N }}\end{array}$ & $\begin{array}{l}\text { 3. Bought to support } \\
\text { local shops / } \\
\text { suppliers }\end{array}$ & $\begin{array}{l}\text { 4. Actively sought info } \\
\text { on companies' } \\
\text { behaviour/policies }\end{array}$ & $\begin{array}{l}\text { 15. Insufficient } \\
\text { Information }\end{array}$ \\
\hline $\begin{array}{l}\text { 3. Bought to support local } \\
\text { shops / suppliers }\end{array}$ & $\begin{array}{r}1.000 \\
69.000\end{array}$ & $\begin{array}{c}\frac{.389^{\star \star}}{.000} \\
69\end{array}$ & $\begin{array}{l}.015 \\
.452 \\
69\end{array}$ \\
\hline $\begin{array}{l}\text { 4. Actively sought info on } \\
\text { companies' behaviour/ } \\
\text { policies }\end{array}$ & $\begin{array}{c}\frac{.389^{\star \star}}{.000} \\
69\end{array}$ & $\begin{array}{l}1.000 \\
69.000\end{array}$ & $\begin{array}{l}.034 \\
.392 \\
69 \\
\end{array}$ \\
\hline $\begin{array}{l}\text { 15. Insufficient } \\
\text { Information }\end{array}$ & $\begin{array}{l}.015 \\
.452 \\
69\end{array}$ & $\begin{array}{l}.034 \\
.392 \\
69\end{array}$ & $\begin{array}{l}1.000 \\
69.000\end{array}$ \\
\hline
\end{tabular}

*.Correlation is significant at the 0.05 level (1-tailed test)

**. Correlation is significant the 0.01 level (1-tailed test)

Correlation(III)

\begin{tabular}{|c|c|c|c|c|c|}
\hline $\begin{array}{c}\text { PEARSON } \\
\text { CORRELATION } \\
\text { (1-Tailed Test) } \\
\mathbf{N} \\
\end{array}$ & $\begin{array}{l}\text { 11.Consumer } \\
\text { authorities }\end{array}$ & 11.Importers & $\begin{array}{l}\text { 12.Firm's } \\
\text { Ethical } \\
\text { Practices }\end{array}$ & $\begin{array}{l}\text { 13.Reliability } \\
\text { of Information }\end{array}$ & $\begin{array}{l}\text { 14. Ethical } \\
\text { Influence on } \\
\text { Purchases }\end{array}$ \\
\hline $\begin{array}{l}\text { 11. Consumer } \\
\text { authorities }\end{array}$ & $\begin{array}{l}1.000 \\
69.000 \\
\end{array}$ & $\begin{array}{l}.428^{* *} \\
.000 \\
69 \\
\end{array}$ & $\begin{array}{l}.162 \\
.091 \\
69 \\
\end{array}$ & $\begin{array}{l}-.024 \\
.424 \\
69 \\
\end{array}$ & $\begin{array}{l}.228^{*} \\
.030 \\
69 \\
\end{array}$ \\
\hline 11. Importers & $\begin{array}{l}.428^{* *} \\
.000 \\
69 \\
\end{array}$ & $\begin{array}{l}1.000 \\
69.000 \\
\end{array}$ & $\begin{array}{l}.149 \\
.111 \\
69 \\
\end{array}$ & $\begin{array}{l}.144 \\
.120 \\
69 \\
\end{array}$ & $\begin{array}{l}.374^{* *} \\
.001 \\
69 \\
\end{array}$ \\
\hline $\begin{array}{l}\text { 12. Firm's Ethical } \\
\text { Practices }\end{array}$ & $\begin{array}{l}.162 \\
.091 \\
69 \\
\end{array}$ & $\begin{array}{l}.149 \\
.111 \\
69 \\
\end{array}$ & $\begin{array}{l}1.000 \\
69.000\end{array}$ & $\begin{array}{l}.220^{*} \\
.035 \\
69 \\
\end{array}$ & $\begin{array}{l}.389^{* *} \\
.000 \\
69\end{array}$ \\
\hline $\begin{array}{l}\text { 13. Reliability of } \\
\text { Information }\end{array}$ & $\begin{array}{l}-.024 \\
.424 \\
69 \\
\end{array}$ & $\begin{array}{l}.144 \\
.120 \\
69 \\
\end{array}$ & $\begin{array}{l}.220^{*} \\
.035 \\
69 \\
\end{array}$ & $\begin{array}{l}1.000 \\
69.000\end{array}$ & $\begin{array}{l}.129 \\
.144 \\
69 \\
\end{array}$ \\
\hline $\begin{array}{l}\text { 14. Ethical Influence } \\
\text { on Purchases }\end{array}$ & $\begin{array}{l}.228^{*} \\
.030 \\
69\end{array}$ & $\begin{array}{l}.374^{* *} \\
.001 \\
69\end{array}$ & $\begin{array}{l}.389^{* *} \\
.000 \\
69\end{array}$ & $\begin{array}{l}.129 \\
.144 \\
69\end{array}$ & $\begin{array}{l}1.000 \\
69.000\end{array}$ \\
\hline
\end{tabular}

*. Correla tion is significant at the 0.05 level (1-tailed test)

**. Correlation is significant the 0.01 level (1-tailed test) 